\title{
Dual benefits of polyacrylamide and other soil amendments: Mitigation of soil nutrient depletion and improvement of use-efficiency in midland agro-ecology, Ethiopia
}

Temesgen Mulualem ${ }^{1}$, Enyew Adgo ${ }^{1}$, Derege Meshesha ${ }^{1}$, Atsushi Tsunekawa ${ }^{2}$, Nigussie Haregeweyn $^{3}$, Mitsuru Tsubo ${ }^{4}$, Birhanu Kebede ${ }^{5}$, Kindiye Ebabu ${ }^{6}$, Mulatu Berihun ${ }^{5}$, Anteneh Wubet ${ }^{1}$, Genetu Fekadu ${ }^{1}$, Simeneh Demissie ${ }^{1}$, and Tsugiyuki Masunaga ${ }^{7}$

${ }^{1}$ Bahir Dar University College of Agriculture and Environmental Sciences

${ }^{2}$ Tottori University - Tottori Campus

${ }^{3}$ International Platform for Dryland Research and Education, Tottori University, Japan

${ }^{4}$ Tottori Daigaku - Tottori Campus

${ }^{5}$ Bahir Dar Polytechnic Institute

${ }^{6}$ Tottori University

${ }^{7}$ Shimane Daigaku

March 3, 2022

\begin{abstract}
Mitigating soil nutrient depletion and increasing utilization efficiency is a prerequisite of sustainable agriculture. Therefore, a field experiment was carried out for 2 years in the midland agroecology of Ethiopia, to identify soil amendment types that can improved soil nitrogen $(\mathrm{N})$ and phosphorus $(\mathrm{P})$ balances at the same time maximize utilization efficiency and profitability under teff cultivation. Using RCBD with three replications, the soil amendments applied on the degraded acidic farmland plots were polyacrylamide $(\mathrm{PAM}=40 \mathrm{~kg}$ ha- 1$)$, biochar $(\mathrm{B}=8 \mathrm{t}$ ha- 1$)$, lime $(\mathrm{L}=4 \mathrm{t}$ ha- 1$)$, gypsum $(\mathrm{G}=5 \mathrm{t}$ ha- 1$), \mathrm{PAM}+\mathrm{B}, \mathrm{PAM}+\mathrm{L}$, $\mathrm{PAM}+\mathrm{G}$, and a control. $\mathrm{N}$ and $\mathrm{P}$ inflows from (atmospheric deposition, biological fixation, and fertilizers), and outflows by (water erosion, leaching, gaseous emissions, and harvested products) were monitored in the 24 plots via NUTrient MONitoring model. Results showed that all of the applied soil amendments improved nutrient balances (by 8-134\%) compared with the control. Of the measured outflows, harvested products (43-60\%) and water erosion (14-31\%) were the major contributors to $\mathrm{N}$ depletion, followed by leaching (15-23\%) and gaseous emissions (11-13\%). Among the applied soil amendments, PAM+L appreciably reduced $\mathrm{P}$ loss from water erosion by $61 \%$ and $\mathrm{N}$ losses from erosion, leaching, and emissions by $55 \%, 10 \%$, and $3 \%$, respectively, and increased $\mathrm{N}$ use efficiency by $31 \%$ compared to control plot. Moreover, PAM $+\mathrm{L}$ provided a net benefit much higher compared with others. Thus, application of PAM $+\mathrm{L}$ would be an effective strategy to combat nutrient depletion and foster crop production in dryland agriculture.
\end{abstract}

\section{Hosted file}

Manuscrpit. docx available at https : //authorea. com/users/463373/articles/558473-dual-benefitsof-polyacrylamide-and-other-soil-amendments-mitigation-of-soil-nutrient-depletion-andimprovement-of-use-efficiency-in-midland-agro-ecology-ethiopia

\section{Hosted file}

Tables.docx available at https://authorea.com/users/463373/articles/558473-dual-benefitsof-polyacrylamide-and-other-soil-amendments-mitigation-of-soil-nutrient-depletion-and- 
improvement-of-use-efficiency-in-midland-agro-ecology-ethiopia

\section{Hosted file}

Figures.docx available at https://authorea.com/users/463373/articles/558473-dual-benefitsof-polyacrylamide-and-other-soil-amendments-mitigation-of-soil-nutrient-depletion-andimprovement-of-use-efficiency-in-midland-agro-ecology-ethiopia 